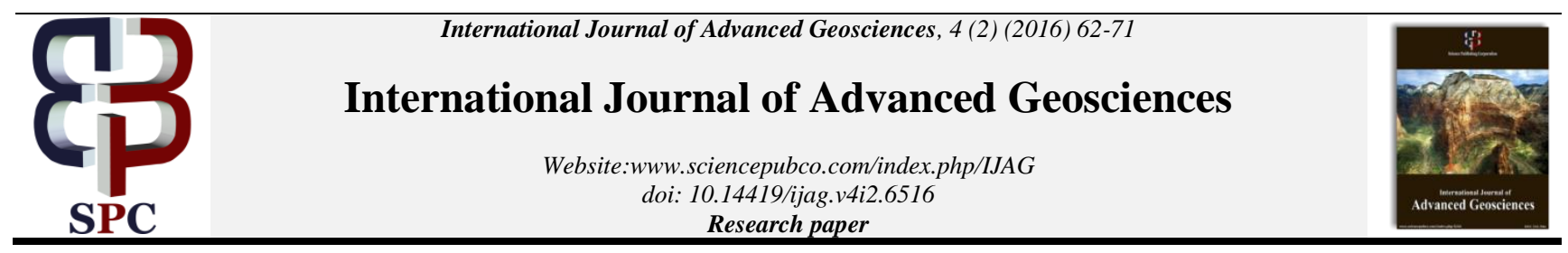

\title{
New K-AR ages of tchabal mbabo alkaline volcano massif, Cameroon volcanic line and adamawa plateau (central Africa)
}

\author{
MefireAminatouFagny ${ }^{1}$, OumarouFaaroukNkouandou $^{1 *}$, Robert Temdjim $^{2}$, Jaques-Marie Bardintzeff $^{3}$, \\ HerveGuillou $^{4}$, Dan Stumbea ${ }^{5}$,AbdelhakBoutaleb ${ }^{6}$ \\ ${ }^{I}$ University of Ngaoundéré, Faculty of Science, P.o. Box 454 Ngaoundéré, Cameroon \\ ${ }^{2}$ University of Yaoundé 1, Faculty of Science, P.o. Box 812 Yaoundé, Cameroon \\ ${ }^{3}$ University Paris-Sud, UMR CNRS 8148 GEOPS, bât. 504, F-91405 Orsay, France \\ ${ }^{4}$ Laboratoire des Sciences du Climat et de l'Environnement, 91198 Gif sur Yvette, France \\ ${ }^{5}$ University "AlexandruIoanCuza" Iași, Department of Geology, $20 \mathrm{~A}$ Carol I Bv, 700505 Iași \\ ${ }^{6}$ Faculté des Sciences de la Terre, de Géographie et de l'Aménagement du Territoire, P.o. Box 32, El Alia, Tunisia \\ *Corresponding author E-mail:ofaarouk@yahoo.fr
}

\begin{abstract}
Tchabal Mbabo in Central Africa is a voluminous volcano massif composed of alkali lava series. K-Ar geochronology data obtained from three samples of basanite - trachyandesite composition defined at least two volcanic activities. The first at end Eocene (38.22 \pm 0.80 $\mathrm{Ma})$ and the second during Oligocene $(28.88 \pm 0.61$ and $28.60 \pm 0.60 \mathrm{Ma})$. The distribution of different ages along the Cameroon Volcanic Line is difficult to council with any migration of magmatic activity, as previously suggested. The most realistic scenario for the formation of Cameroon Line is that the ascent of lavas has been favored by the crustal discontinuities inherited from the Pan-African orogeny and reactivated during Mesozoic and Cenozoic. ICP MS and ICP AES analyses show that basanite lavas are the result of $2 \%$ melting of sub-lithospheric mantle source containing garnet and phlogopite phases; the trachyandesites are formed by fractional crystallization of K-feldspar, amphibole, clinopyroxene and Fe-Ti oxides.
\end{abstract}

Keywords: K-Ar Age; Tchabal Mbabo Volcano; Cameroon Volcanic Line; Adamawa Plateau; Central Africa.

\section{Introduction}

The Tchabal Mbabo massif is a huge Cenozoic volcano that crops out at the cross intersection of well-known magmatic provinces of Cameroon Volcanic Line (CVL) and Adamawa plateau (AP) in Central Africa (Fig. 1). These tectono-magmatic structures have concentrated the major part of Central Africa magmatism with those of Benue trough. They are bordered by the Central Africa Shear Zone (CASZ) which crosscuts both the continental crust and the upper mantle down to a depth of $190 \mathrm{~km}$ (Dorbath et al. 1986). The Tchabal Mbabo massif, $2500 \mathrm{~m}$ height and stretching 30 x $54 \mathrm{~km}$, marks the Adamawa plateau. It overhangs the western Koutine plain in the West, Kontcha basin to the North, Galim and Sambolabo lowlands to the East and South, respectively. The previous K-Ar (Dunlop 1983; Fitton\& Dunlop 1985; Fitton 1987) and ${ }^{40} \mathrm{Ar} /{ }^{39} \mathrm{Ar}$ ages (Lee et al., 1994a, 1994b; Marzoli et al. 1999), determined on volcanic massifs and lava flows from CVL and AP, do not clearly support a hot-spot origin as the model of Wilson-Morgan (Wilson 1965, 1973; Morgan 1971, 1972a,b). Then, the lack of age progression along the CVL magmatism renders the age determination of each volcano of the line indispensable to modelize the entire CVL. Moreover, the AP geochronology (Gouhier et al. 1974; Temdjim et al. 2004; Nkouandou et al. 2008 ; Fagny et al. 2012) evidenced that these volcanoes are relatively more recent (11 Ma to recent) than those of the CVL (up to 70 Ma to recent, Mbowou et al. 2012). Thus, whether the AP magmatism belongs to CVL, as proposed in the Y-shaped model for the whole CVL (Fitton, 1980,

1983), though largely debated (Gouhier et al. 1974; Aka et al. 2004, 2009; Nkouandou et al. 2010), remains questionable and requires many more age determinations. We contribute to this debate by producing a new geochronology base on the K-Ar dating of alkali intraplate volcanic massif of Tchabal Mbabo in the Cameroon volcanic Line. 


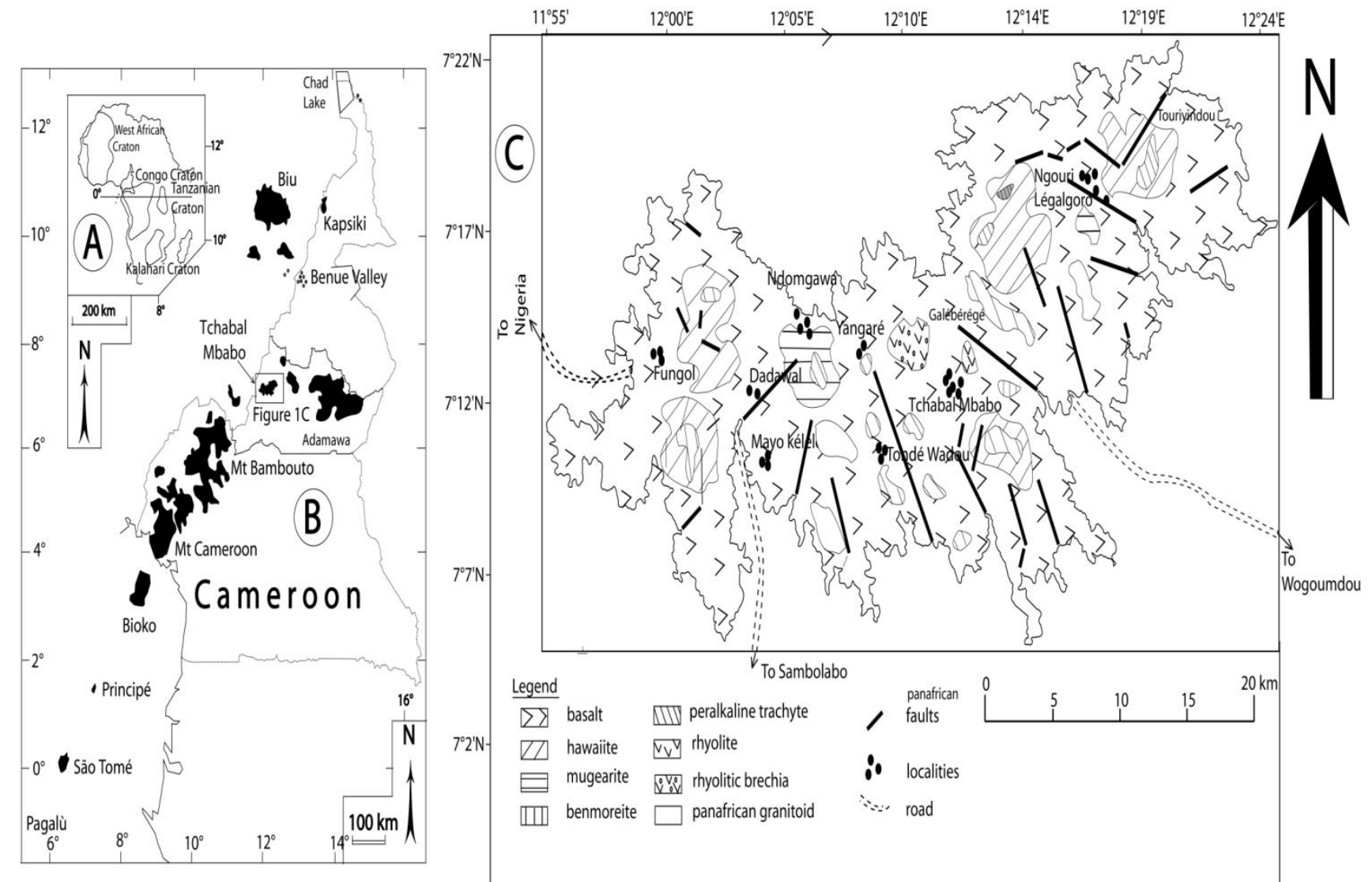

Fig. 1: A: Main Cratonsof Africa Plate (after Kampunzu\&Popoff1991), B: Cameroon Volcanic Line (after DéruelleEt Al. 1991, Modified) and C: the Geological Map of Tchabal Mbabo Volcano.

\section{Geological setting}

The Cameroon Volcanic Line (CVL), in central Africa (Fig. 1), is a $1600 \mathrm{~km}$ long volcanic chain which straddles both the Atlantic Ocean crust and continental Pan-African crust of Cameroon, from Pagalu in the Gulf of Guinea to nearby Lake Chad (Déruelle et al. 2007). It intersects the Adamawa plateau at the Tchabal Mbabo volcano (Déruelle et al. 1990) and ends in the Chad Lake neighbourhood, in the northernmost Cameroon and southern Chad Republic. To explain the formation of the CVL, numerous interpretations were discussed, the most important of which can be found in Déruelle et al. (1991). The most widely accepted structural model is that $\mathrm{CVL}$ is due to a rejuvenation of the pan-African fracture zone, $\mathrm{N} 70^{\circ} \mathrm{E}$ oriented, at the beginning of the Central Atlantic Ocean opening (Moreau et al. 1987). The Tchabal Mbabo basement consists of granitic and gnessic rocks, rising up to $2100 \mathrm{~m}$ Those rocks are probably Pan African in age, as shown by those described at Méiganga (Ganwa et al. 2008) and northern Ngaoundéré, with ages of $610-652 \pm 54 \mathrm{Ma}$ and $926 \pm 12 \mathrm{Ma}$ (Tchameni et al. 2006), which place them within the Central Pan-African Chain (CPAC). CVL is composed of volcanic centres and anorogenic complexes with volcanic rocks, forming a chain of Tertiary to recent lavas (Déruelle et al. 1991; Kamden et al. 2002; Kamgang et al. 2010; Mbowou et al. 2012). Continental magmas evolve towards peralkaline rhyolite lavas, whereas those in the oceanic sector evolve towards phonolites (Fitton 1987). This points out the progressive crustal contamination of the continental magmas, accompanied by a crystal fractionation, to explain this distinction.

\section{Analytical methods}

Petrographic analyses of the studied rocks were carried out on 7 thin sections, prepared from the most representative samples of the lavas at the Laboratory of Geosciences GEOPS, University ParisSud Orsay and Centre de Recherches Pétrographiques et Géochimiques (CRPG) of Nancy, both in France. Major element analyses have been carried out by ICP-OES (Inductively Coupled Plasma - Optical Emission Spectrometry) and trace element analyses by ICP-MS (Inductively Coupled Plasma - Mass Spectrometry). During the preparation of samples, about $300 \mathrm{mg}$ of powder have been treated with $\mathrm{LiBO}_{2}$ and dissolved in $\mathrm{HNO}_{3}$. Five international geostandards have been used, as follows: basalt BR, diorite DRN, serpentinite UBN, anorthosite ANG and granite GH (Carignan et al. 2001).

Minerals have been analysed with a CAMECA SX 100 electron microprobe $(15 \mathrm{kV}, 10 \mathrm{nA})$, at Université Pierre et Marie Curie, Paris VI, France; for this purpose, $\mathrm{K} \alpha$ lines were used. The chemical composition was determined using the following standards: diopside for $\mathrm{Si}$, $\mathrm{Ca}$ and $\mathrm{Mg} ; \mathrm{Fe}_{2} \mathrm{O}_{3}$ for $\mathrm{Fe} ; \mathrm{MnTiO}_{3}$ for $\mathrm{Ti}$ and $\mathrm{Mn}$; $\mathrm{Cr}_{2} \mathrm{O}_{3}$ for $\mathrm{Cr}$; albite for $\mathrm{Na}$; orthoclase for $\mathrm{K}$ and $\mathrm{Al}$. The counting times were $10 \mathrm{~s}$ for $\mathrm{Pk}$ (peaks) and $10 \mathrm{~s}$ for $\mathrm{Bg}$ (background), with a $5 \mu \mathrm{m}$ defocused beam. As standards, a combination of natural and synthetic minerals were used. Data corrections were made using the PAP method correction of Pouchou and Pichoir (1991).

Three samples (M4, M12 and MB17) were K-Ar dated, at the Laboratoire des Sciences du Climat et Environnement, Gif-SurYvette, France.

Groundmass was separated from phenocrysts and other phases using a Sm-Co magnetic and heavy liquid, followed by handpicking under a binocular microscope.

All the samples were dated using the unspiked K-Ar technique described by Charbit et al. (1998). This technique differs from the conventional isotope dilution method in that argon extracted from the sample is measured in sequence with purified aliquots of atmospheric argon at the same working gas pressure in the massspectrometer. The determination of $\mathrm{K}$ was carried out by atomic absorption with a relative precision of $1 \%$. Argon was extracted by radio frequency heating of a $300 \mathrm{mg}$ sample in an ultra-highvacuum glass line and purified with $\mathrm{Ti}$ sponge and $\mathrm{Zr}$ - $\mathrm{Al}$ getters. Isotopic analyses were performed on total ${ }^{40} \mathrm{Ar}$ contents ranging between $2.910^{-11}$ and $1.0 \times 10^{-10} \mathrm{~mol}$ using a $180^{\circ}, 6 \mathrm{~cm}$ radius mass spectrometer equipped with a double faraday collector allowing the simultaneous measurement of ${ }^{36} \mathrm{Ar}$ and ${ }^{40} \mathrm{Ar}$ at an ac- 
celerating potential of $620 \mathrm{~V}$. The manometric calibration is based on periodic replicate determinations of international dating standards of known $\mathrm{K}-\mathrm{Ar}$ age using the same procedure as for the unknown samples to be measured as described in Charbit et al (1998). This allows the total ${ }^{40} \mathrm{Ar}$ content of the sample to be determined with a precision of about $\pm 0.2 \%(2 \sigma)$. Used standard is HD-B1 dated $24.21 \pm 0.32 \mathrm{Ma}$, (Fuhrmann et al. 1987; Hess and Lippolt 1994; Hautmann and Lippolt 2000).

\section{Results}

\subsection{K-Ar geochronology}

Lavas have been identified according to IUGS classification (after Le Maître, 2002) as: basalt (M4) (45 wt\% < $\mathrm{SiO}_{2}<52 \mathrm{wt} \%$ and normative olivine of $8 \%$ ); basanite (MB12) $\left(\mathrm{SiO}_{2}<45 \mathrm{wt} \%\right.$ and normative olivine > $10 \mathrm{wt} \%$ ); and trachyandesite (57 wt \% < $\mathrm{SiO}_{2}<63 \mathrm{wt} \%$, MB17).

The K-Ar ages are reported in Table 1. For each sample, three independent measurements of $\mathrm{K}$ were carried out. Potassium concentrations were combined to yield a mean value. Age determinations of each sample were made using this value and the weighted mean of the two independent measurements of ${ }^{40} \mathrm{Ar} *$ (radiogenic argon). Uncertainties for the Ar data are $1 \sigma$ analytical only, and consist of propagated and quadratically averaged experimental uncertainties arising from the ${ }^{40} \mathrm{Ar}$ (total), and ${ }^{40} \mathrm{Ar} *$ determinations. Uncertainties on the ages are given at $2 \sigma$.

Ages are $28.88 \pm 0.61 \mathrm{Ma}$ (basalt), $28.60 \pm 0.60 \mathrm{Ma}$ (basanite) and $38.22 \pm 0.80$ (trachyandesite) (Table 1). Therefore, the Tchabal Mbabo volcanic massif was emplaced in his present area during Paleogene, i.e., end Eocene-Oligocene.

Table 1: K-ArAge Data of Lavas

\begin{tabular}{|c|c|c|c|c|c|c|}
\hline Sample & $\mathrm{K}(\mathrm{wt} \%) \pm 2 \sigma$ & Mass molten (g) & ${ }^{40} \mathrm{Ar} \%$ & $\begin{array}{l}{ }^{40} \mathrm{Ar} \% 10^{-11} \\
(\mathrm{Mol} . \mathrm{g}) \pm 1 \sigma\end{array}$ & $\begin{array}{l}{ }^{40} \mathrm{Ar} \% 10^{-11} \\
(\mathrm{Mol} . / \mathrm{g}) \pm 1 \sigma \\
\text { Weighted mean }\end{array}$ & $\begin{array}{l}\text { Age (Ma) } \\
\pm 2 \sigma\end{array}$ \\
\hline \multicolumn{7}{|l|}{ M12 } \\
\hline 8711 & $1.544 \pm 0.015$ & 0.31658 & 83.216 & $7.681 \pm 0.039$ & & \\
\hline 8726 & « $\ldots \ldots \ldots \ldots \ldots, \|$ & 0.31879 & 84.052 & $7.755 \pm 0.039$ & $7.718 \pm 0.027$ & $28.60 \pm 0.60$ \\
\hline \multicolumn{7}{|l|}{ M4 } \\
\hline 8724 & $1.004 \pm 0.014$ & 0.30405 & 22.190 & $5.073 \pm 0.025$ & & \\
\hline 8725 & $\langle\ldots \ldots \ldots \ldots \ldots\rangle$ & 0.34671 & 23.361 & $5.065 \pm 0.025$ & $5.069 \pm 0.018$ & $28.88 \pm 0.61$ \\
\hline \multicolumn{7}{|l|}{ MB17 } \\
\hline 8712 & $4.317 \pm 0.043$ & 0.30645 & 89.421 & $28.710 \pm 0.144$ & & \\
\hline 8727 & $\langle\ldots \ldots \ldots \ldots \ldots\rangle$ & 0.31432 & 70.408 & $29.132 \pm 0.146$ & $28.918 \pm 0.102$ & $38.22 \pm 0.80$ \\
\hline
\end{tabular}

\subsection{Petrography and mineralogy of dated lavas}

Two dated basalt-basanite lavas have microlitic porphyritic texture (Fig. 2. A, B, C, D, E and F). They are composed of olivine, clinopyroxene and oxides phenocrysts, disposed in a microlitic matrix consisting of the same minerals as the phenocrysts, plus plagioclases. Brown crystals of amphibole are present in some samples (Fig. 2C). Chemical compositions of representative minerals of dated lavas are presented in Table 2.

Olivine phenocrysts (size of $250 \mu$ to $1,2 \mathrm{~mm}$ ), containing rare oxide microcrysts (Fig. 2A), are less abundant (7 to 10 modal\%); they are euhedral and $\mathrm{Mg}$-rich $\left(\mathrm{Fo}_{64.18-65.76}\right)$. Olivine microcrysts are less magnesian $\left(\mathrm{Fo}_{54}\right)$. $\mathrm{CaO}$ contents are relatively higher in the core $(0.34-0.41 \mathrm{wt} \%)$ compared to rims $(0.33 \mathrm{wt} \%)$; $\mathrm{NiO}$ contents are low $(0.1 \mathrm{wt} \%)$ in phenocrysts.

Clinopyroxene crystals $(60 \mu \mathrm{m}$ to $2 \mathrm{~mm})$ are euhedral (Fig. 2B) and have an abundance of 10 modal $\%$. Some phenocrysts exhibiting corroded rimes are subhedral. Enclosed oxide microcrysts are frequent. All clinopyroxenes show a diopside $\left(\mathrm{Wo}_{49.4-49.7} \mathrm{En}_{40.4}\right.$ $\left.{ }_{40.5} \mathrm{Fs}_{9.9-9.1}\right)$ to augite $\left(\mathrm{Wo}_{42.0-43.3} \mathrm{En}_{46.2-46.9} \mathrm{Fs}_{9.8-11.8}\right)$ composition (classification scheme of Morimoto et al. 1988). M12 clinopyrox- ene crystals are richer in $\mathrm{TiO}_{2}(1.8-2.2 \mathrm{wt} \%)$ and $\mathrm{Al}_{2} \mathrm{O}_{3}(5 \mathrm{wt} \%)$, relative to $\mathrm{M} 4$ clinopyroxene $\left(\mathrm{TiO}_{2}: 0.2-0.3 \mathrm{wt} \%\right.$ and $\mathrm{Al}_{2} \mathrm{O}_{3}: 2.0-$ $2.6 \mathrm{wt} \%)$.

The plagioclase microlites are dominant within the matrix (60 in volume \%). They have acicular shapes and a labradorite composition $\left(\mathrm{An}_{60.64-58.28} \mathrm{Ab}_{37.14-38.95}\right)$.

The oxides are mainly represented by Ti-magnetite, showing a $\mathrm{TiO}_{2}$ amount of 15-19 wt $\%$ and a $\mathrm{FeO}$ abundance ranging between 77.59 and $78.55 \mathrm{wt} \%$.

Amphiboles appear as euhedral phenocrysts, always crowned by a thin layer consisting of oxide microcrysts. All crystals have a pargasite composition, as shown by the $\mathrm{Si}$ abundance (0.658-0.676 apuf) and $\mathrm{Mg} /\left(\mathrm{Mg}+\mathrm{Fe}^{2+}\right)$ ratio (64.66-68.59) (Leake et al. 1998). Trachyandesite lava exhibits a microlitic porphyric texture. It is composed of phenocrysts of ferroaugite $\left(\mathrm{Wo}_{43.54-44.66} \mathrm{En}_{14.62}\right.$ $\left.{ }_{11.91} \mathrm{Fs}_{45.71-43.44}\right)$ and microlites of andesine $\left(\mathrm{Or}_{7.38-9.69} \mathrm{Ab}_{62.07}\right.$ $\left.{ }_{59.46} \mathrm{An}_{30.55-30.84}\right)$, pargasite, alkali feldspar, oxides $\left(\mathrm{TiO}_{2}: 14-18\right.$ $\mathrm{wt} \%, \mathrm{Al}_{2} \mathrm{O}_{3}:$ 77-78 wt \%), and apatite. The groundmass contains microlites of oligoclase $\left(\mathrm{Or}_{23.07-11.46} \mathrm{Ab}_{64.26-58.55} \mathrm{An}_{12.67-29.99}\right)$ and also of oxides, ferroaugite, feldspar and apatite. 


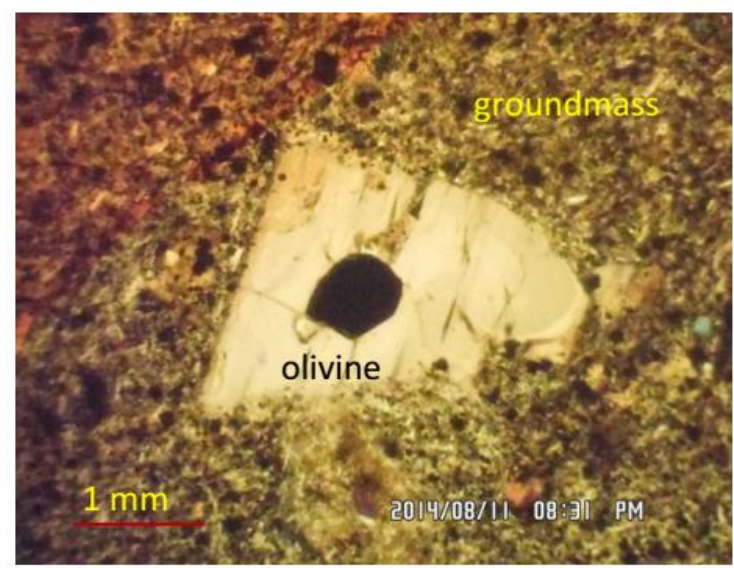

Fig. 2A. Corroded rim of olivine crystal enclosing oxide crystal in the groundmass of plagioclase and oxide microlits of basanite M4.

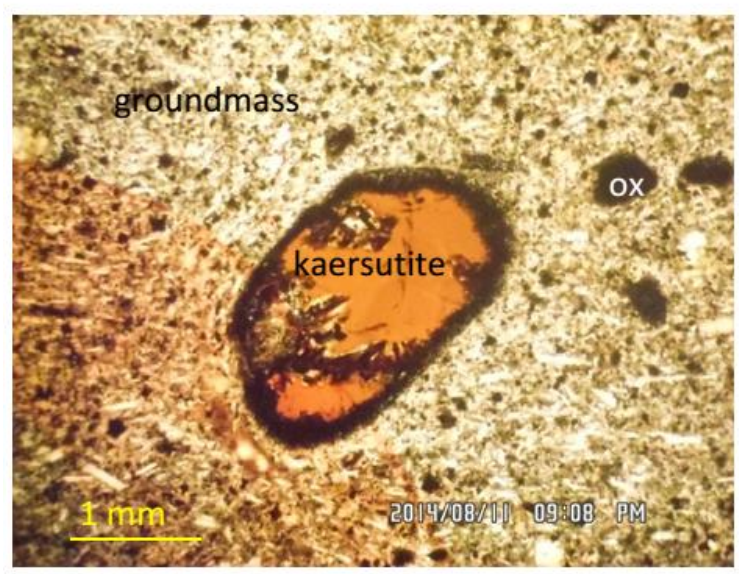

Fig. 2C. Kaersutite amphibole phenocryst encircled by a crown of oxide microcrysts (LAP). Sample M4

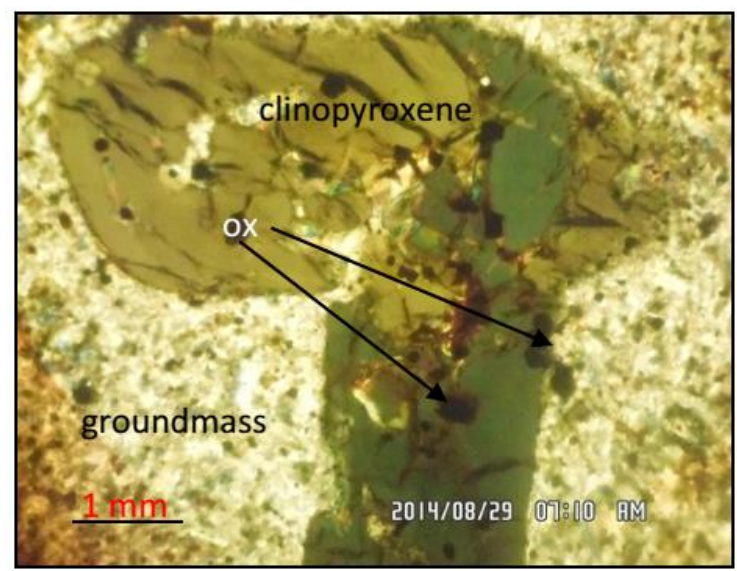

Fig. 2E. Aggregation of skeletal green clinopyroxene phenocrysts, containing angular oxides crystals (LPA). Sample MB17

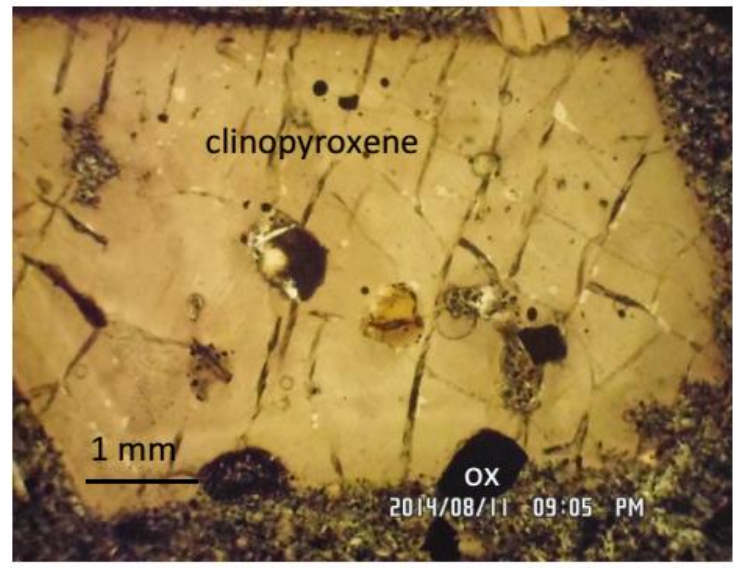

Fig. 2B. Euhedral shape of zoned clinopyroxene crystal in the groundmass of microcrystalized plagioclase and oxides. Basanite M12.

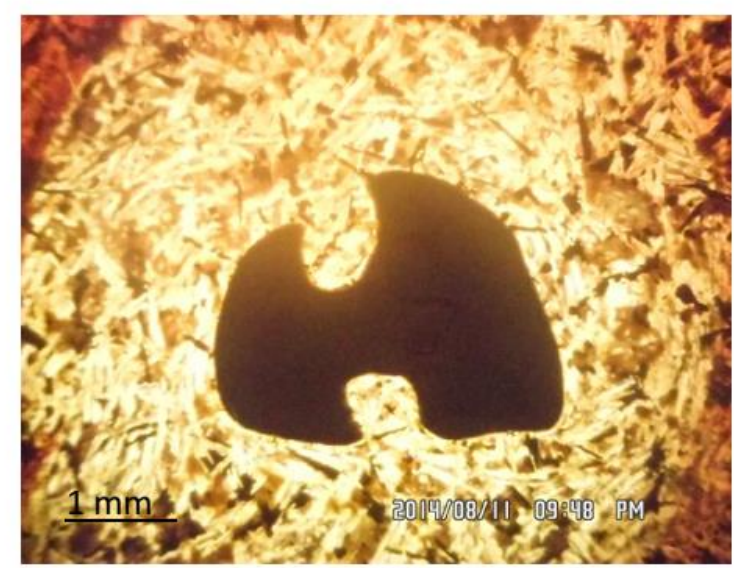

Fig. 2D. Corroded xenocryst of spinel in basanite M12 (LAP).

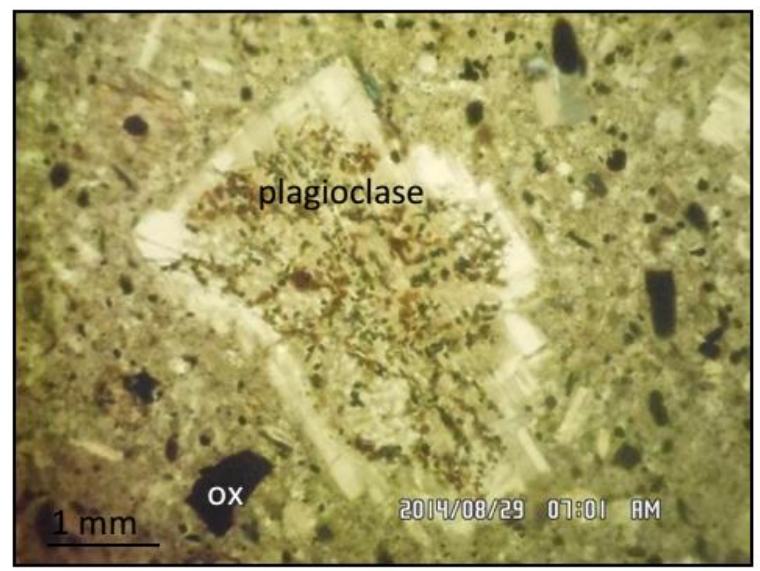

Fig.2F. Resorbed plagioclase phenocrysts, containing tiny oxide crystals (LPA). Sample MB17

Fig. 2:Microphotographs of Studied Lavas. 
Table 2: Chemical Composition of Representative Minerals of Dated Lavas

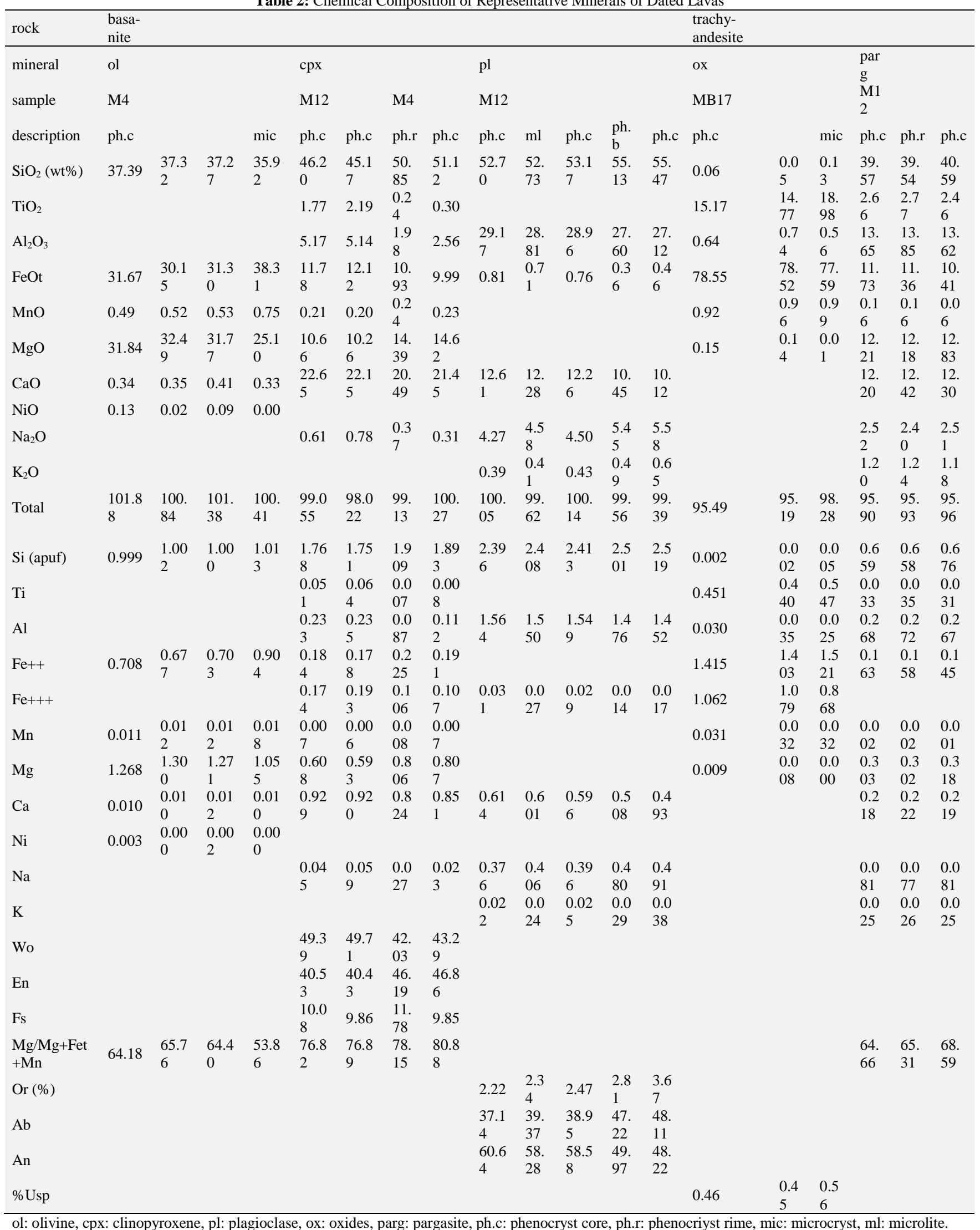

\subsection{Geochemistry of dated lavas}

The abundance of major and trace elements of selected lavas used in this study are presented in Table 3. Major elements exhibit features typical to alkali lavas worldwide, such as high $\mathrm{TiO}_{2}$ (up to $4 \mathrm{wt} \%$ ) and high sum of alkalis (between 4 and $10 \mathrm{wt} \%$ ).

Contents of REE within the lavas (42 to 124 times the mantle values) are normalized to Primitive Mantle (after Hofmann 1988) and illustrated in Fig. 3. All lavas are characterized by the very high contents of LREE relative to HREE, exhibiting a gentle slope pattern. There is no particular anomaly, even in $\mathrm{Eu}$, while $\mathrm{CeN} / \mathrm{YbN}$ ratios of basaltic lavas range between 7.5 and 12.1.

Trace elements contents of studied lavas also were normalized to Primitive Mantle (after Hofmann 1988). These patterns, presented in Fig. 4, are similar to those of Cenozoic alkali lavas studied in the Cameroon Line (Kamgang et al. 2010), Adamawa plateau (Nono et 
al. 1994; Nkouandou et al. 2008 \& 2010) and world-wide. The patterns display roughly the same configuration, with increased contents showed by $\mathrm{Rb}$ and especially $\mathrm{Ba}$, and followed by regularly decrease towards Lu. Negative anomalies are recorded by Th, U, $\mathrm{K}, \mathrm{P}$ and, partially, Ti. Positive anomalies are noticed for $\mathrm{Nb}, \mathrm{Ta}$ and Sr. For trachandesite, there are noteworthy negative anomalies in $\mathrm{P}, \mathrm{Sr}$ and $\mathrm{Ti}$. This pattern is particular in positive $\mathrm{K}$ anomaly. Ratios of $\mathrm{Nb} / \mathrm{Ta}$ (13.3-1.9) and $\mathrm{Zr} / \mathrm{Hf}$ (39.2-43.8) are roughly constant.

Table 3:Whole Rock Chemical Analyses of Studied Lavas

\begin{tabular}{|c|c|c|c|}
\hline Lava & Basalt & Basanite & Trachyandesite \\
\hline $\begin{array}{l}\text { Sample } \\
\text { (wt\%) }\end{array}$ & M4 & M12 & MB17 \\
\hline $\mathrm{SiO}_{2}$ & 46.41 & 42.97 & 60.35 \\
\hline $\mathrm{TiO}_{2}$ & 3.25 & 3.99 & 0.60 \\
\hline $\mathrm{Al}_{2} \mathrm{O}_{3}$ & 15.83 & 14.94 & 14.75 \\
\hline $\mathrm{Fe}_{2} \mathrm{O}_{3}$ & 11.93 & 12.70 & 9.04 \\
\hline $\mathrm{MnO}$ & 0.17 & 0.21 & 0.23 \\
\hline $\mathrm{MgO}$ & 5.95 & 6.35 & 0.25 \\
\hline $\mathrm{CaO}$ & 9.68 & 10.02 & 2.67 \\
\hline $\mathrm{Na}_{2} \mathrm{O}$ & 2.83 & 3.90 & 4.54 \\
\hline $\mathrm{K}_{2} \mathrm{O}$ & 1.09 & 1.64 & 5.21 \\
\hline $\mathrm{P}_{2} \mathrm{O}_{5}$ & 0.39 & 0.96 & 0.16 \\
\hline LOI & 3.14 & 1.37 & 1.44 \\
\hline sum & 100.67 & 99.07 & 99.22 \\
\hline \multicolumn{4}{|c|}{ CIPW norm (\%) } \\
\hline Quartz & 0.00 & 0.00 & 5.65 \\
\hline Corundum & 0.00 & 0.00 & 0.00 \\
\hline Orthoclase & 6.44 & 9.70 & 30.78 \\
\hline Albite & 23.98 & 12.69 & 38.43 \\
\hline Anorthite & 27.26 & 18.43 & 4.46 \\
\hline Leucite & 0.00 & 0.00 & 0.00 \\
\hline Nepheline & 0.00 & 10.99 & 0.00 \\
\hline Diopside & 14.91 & 20.46 & 6.82 \\
\hline Wollastonite & 0.00 & 0.00 & 0.00 \\
\hline Hypersthene & 4.17 & 0.00 & 6.62 \\
\hline Olivine & 10.59 & 12.30 & 0.00 \\
\hline Magnetite & 2.06 & 2.19 & 2.78 \\
\hline Ilmenite & 6.17 & 7.58 & 1.14 \\
\hline Haematite & 0.00 & 0.00 & 0.00 \\
\hline Apatite & 0.90 & 2.22 & 0.37 \\
\hline \multicolumn{4}{|l|}{ (ppm) } \\
\hline $\mathrm{Be}$ & 0.91 & 1.70 & 2.62 \\
\hline $\mathrm{Rb}$ & 33.12 & 36.95 & 79.5 \\
\hline $\mathrm{Sr}$ & 827 & 1160 & 102 \\
\hline Cs & 0.64 & 0.42 & 0.22 \\
\hline $\mathrm{Ba}$ & 371 & 690 & 1545 \\
\hline V & 253.7 & 263.6 & $<$ d.1. \\
\hline $\mathrm{Cr}$ & 130 & 147 & 6 \\
\hline Co & 41.97 & 37.47 & 0.96 \\
\hline $\mathrm{Ni}$ & 54.53 & 55.29 & $<$ d.l. \\
\hline $\mathrm{Cu}$ & 31.60 & 39.22 & 14.17 \\
\hline $\mathrm{Zn}$ & 130 & 133 & 163 \\
\hline $\mathrm{Y}$ & 23.94 & 31.8 & 44.74 \\
\hline $\mathrm{Zr}$ & 190 & 280 & 607 \\
\hline $\mathrm{Nb}$ & 33.68 & 76.24 & 69.45 \\
\hline $\mathrm{Hf}$ & 4.85 & 6.38 & 14.16 \\
\hline Ta & 2.53 & 5.54 & 4.99 \\
\hline Th & 2.41 & 4.25 & 8.70 \\
\hline $\mathrm{U}$ & 0.66 & 1.21 & 2.14 \\
\hline $\mathrm{Pb}$ & 9.15 & 2.943 & 28.90 \\
\hline $\mathrm{La}$ & 25.87 & 55.42 & 76.28 \\
\hline $\mathrm{Ce}$ & 58.67 & 115.90 & 157.90 \\
\hline $\mathrm{Pr}$ & 7.59 & 14.20 & 18.75 \\
\hline $\mathrm{Nd}$ & 31.81 & 57.44 & 73.34 \\
\hline Sm & 6.92 & 11.31 & 14.22 \\
\hline $\mathrm{Eu}$ & 2.34 & 3.67 & 5.44 \\
\hline $\mathrm{Gd}$ & 5.97 & 9.10 & 11.25 \\
\hline $\mathrm{Tb}$ & 0.86 & 1.25 & 1.61 \\
\hline Dy & 4.95 & 6.84 & 9.21 \\
\hline Ho & 0.94 & 1.27 & 1.76 \\
\hline $\mathrm{Er}$ & 2.31 & 3.05 & 4.53 \\
\hline $\mathrm{Tm}$ & 0.31 & 0.39 & 0.63 \\
\hline $\mathrm{Yb}$ & 2.01 & 2.49 & 4.28 \\
\hline $\mathrm{Lu}$ & 0.29 & 0.35 & 0.67 \\
\hline
\end{tabular}

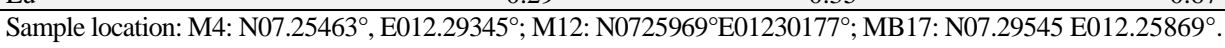




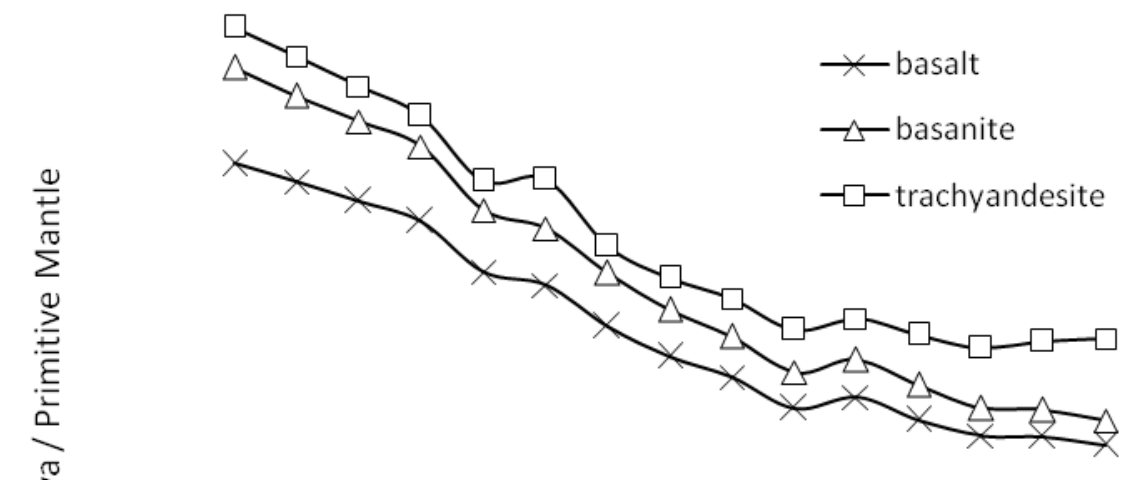

Fig. 3:REE Patterns of Dated Lavas from Tchabal Mbabo (Normalization after Hofmann 1988).

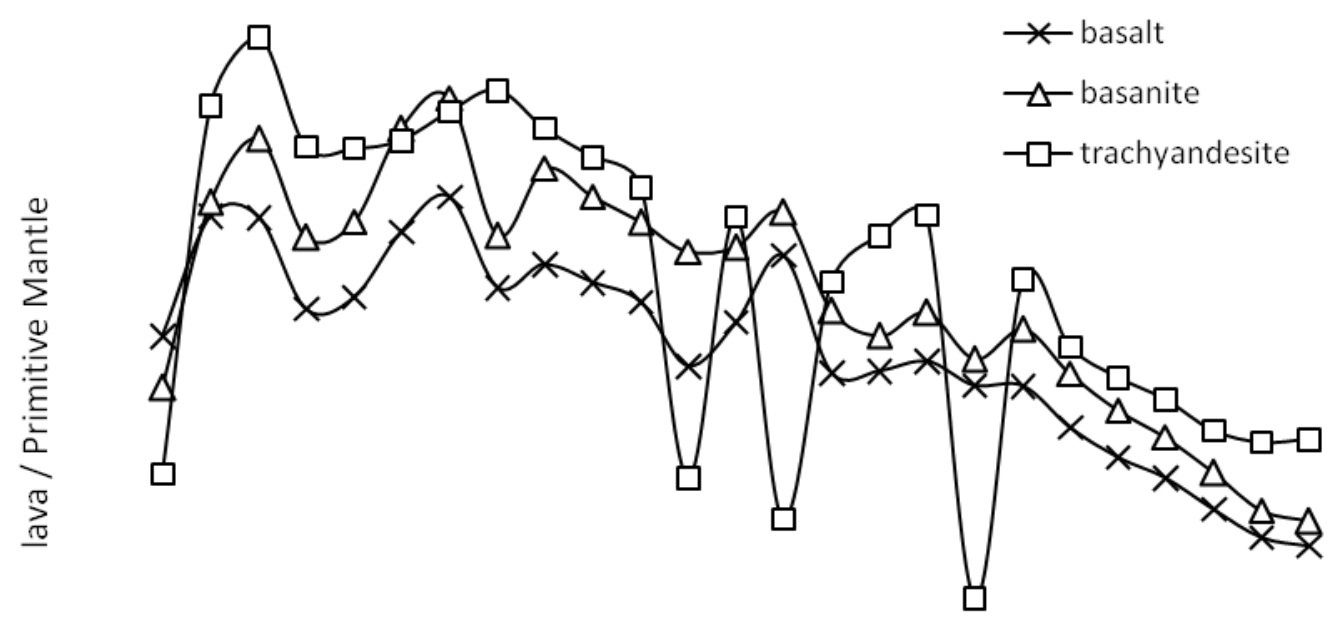

Fig. 4:Primitive Mantle Normalized Multi-Element Diagrams for Dated Lavas from Tchabal Mbabo Volcano (Normalization after Hofmann 1988).

\section{Discussions}

The K-Ar ages of $28.88 \pm 0.61 \mathrm{Ma}, 28.60 \pm 0.60 \mathrm{Ma}$ and $38.22 \pm 0.80$ Ma suggest that more than one eruptive episode have occurred at Tchabal Mbabo volcanic massif. The differentiate trachyandesite is $10 \mathrm{Ma}$ older than the basaltic lavas. This indicates that basaltic and trachyandesite do not belong to the same lava series, although they may evolve from the same source or sources of similar composition. At more than $200 \mathrm{~km}$ north and east from Ngaoundéré, $\mathrm{K}-\mathrm{Ar}$ ages of 7.8 $\pm 1.4 \mathrm{Ma}$ have been obtained for a basalt sample, as well as $8.3 \pm 0.5-10.9 \pm 0.4 \mathrm{Ma}$ ages for four felsic lavas (Nkouandou et al. 2008). One basalt of ankaramitic composition and two trachytic lavas have also been dated as 7.2, 7.8 and 9.8 Ma at Tchabal Nganha volcano massif, by Gouhier et al. (1974). Moreover, Temdjim et al. (2004) determine the ages of some lavas from the Ngaoundéré area, as follows: $6.2 \pm 0.2$ Ma for one hawaiite sample, $6.5-6.8 \pm 0.1 \mathrm{Ma}$ for two phonolites and $0.91 \pm 0.06 \mathrm{Ma}$ for a mugearite.

\subsection{Origin of the Cameroon volcanic line}

It appears that the volcanic eruptions occurring in Adamawa plateau were more recent compared to Tchabal Mbabo volcanic activity and some of the major volcanic eruptions of the Cameroon Line (Fig. 5). At Mont Cameroon, the only active volcano massif of the Cameroon Line, $\mathrm{K}-\mathrm{Ar}$ ages range from $2.83 \pm 0.11$ to $0.00 \pm 0.09 \mathrm{Ma}$ and from $20 \pm 3$ to $29 \pm 2 \mathrm{Ma}$ (Wandji et al. 2009). Therefore, it seems like Tchabal Mbabo volcano massif belongs rather to the Cameroon Volcanic Line than to Adamawa plateau province. However, a distinction between the Cameroon Volcanic Line and Adamawa volcanism is difficult to be made (Fitton 1983). Those observations show that the volcanic manifestations occur diversely along the Cameroon Line and Adamawa plateau, as shown in Fig. 6 (Déruelle et al. 2007, modified and references herein), probably according to the weaknesses conffered by the underneath continental crust in each volcanic area. In this regard, the formation of the Cameroon Line is difficult to council with 
any space-time relationships, especially the hot-spot model of Wilson-Morgan (Wilson 1965, 1973; Morgan 1971, 1972a,b, 1981). The most realistic conception regarding the Cameroon line and Adamawa volcanism is that they have resulted from the rejuvenation of the Pan-African faults, inherited from the Pan-African orogeny and reactivated during Mesozoic and Cenozoic (Moreau et al. 1987). Those faults have crosscut the continental crust down to the mantle (Dorbath et al. 1984) and served as pathway for magma, to reach the surface. Thus, the hot-spot model suggested by Marzoli et al. (1999), also for the oceanic sector of the Cameroon Line volcanism, seems not to be realistic.

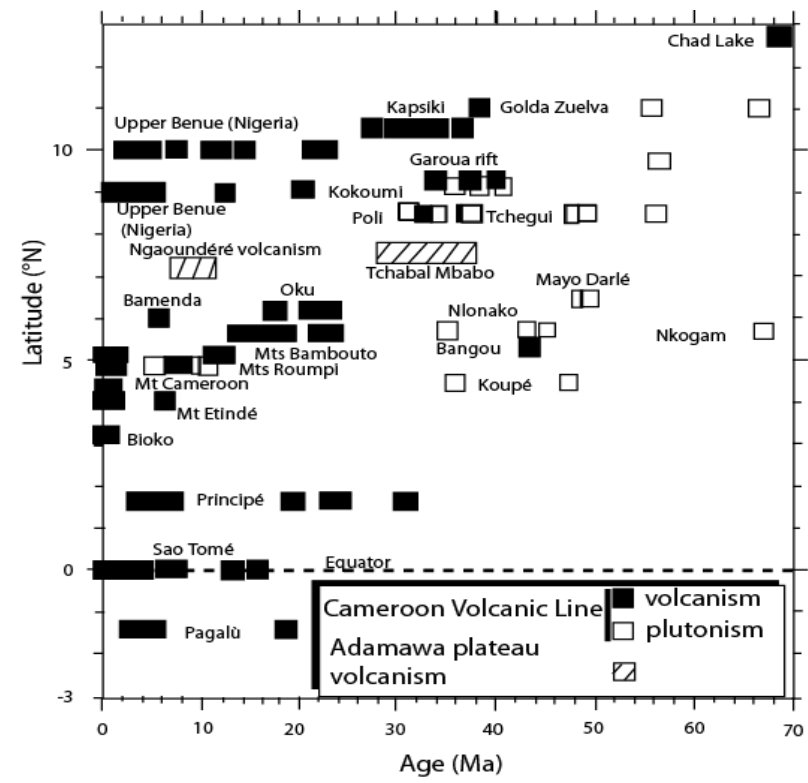

Fig. 5:Age Distribution of volcanoes and anorogenic plutons along the Cameroon Line (Déruelle et Al. 2007, Modified) and Adamawa Plateau (Nkouandou et al. 2008).

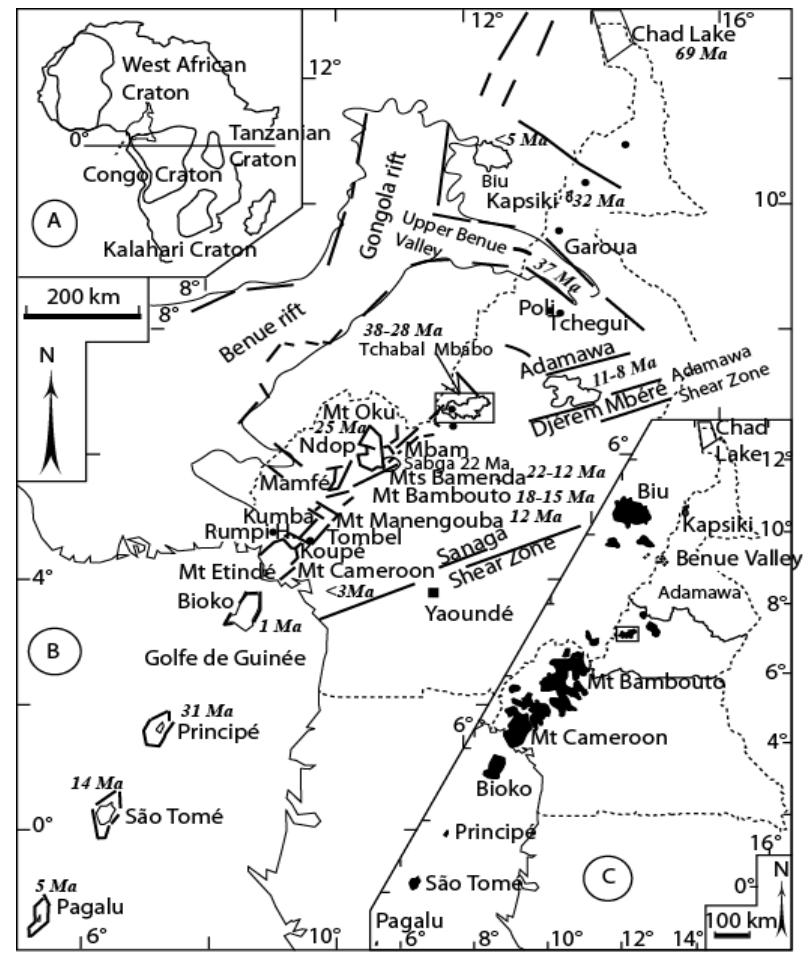

Fig. 6: Location of the Tchabal Mbabo Volcano in the Cameroon Volcanic Line Volcanism and Adamawa Plateau. (A): Main African Cartons (after Kampunzu\&Popoff1991); (B): Horst Structure of the Cameroon Line (Modified); and (C): Mains Volcanoes Location along the Cameroon Line (after Déruelle et al. 1991).

\subsection{Origin of lavas}

The origin of Tchabal Mbabo lavas is widely discussed by Fagny (2016). Determination of the partial melting rate for Tchabal Mbabo volcanism using the method of fractional melting has been attempted. The high Cen/Ybn ratios (7-12) are consisting with a low partial melting rate. A model of partial melting of about $2 \%$ of a deep mantle source (more than $80 \mathrm{~km}$ ), containing garnet and small amounts of phlogopite is proposed for Tchabal Mbabo basanite lavas. The presence of garnet and phlogopite phases within the source is proved by the low values of heavy REE (Wilson 1973 ) and the negative $\mathrm{K}$ anomaly of those lavas (Chauvel et al. 1992). The magma mixing is presumed for basanite of Tchabal Mbabo as the occurrence of plagioclase and spinel xenocrysts in those lavas suggest (Fig. 2D). The pressures in the melting zone calculated using Scarrow and Cox (1995) formula are between 2.49 and $4.3 \mathrm{GPa}$, corresponding to depths of 82 and $143 \mathrm{~km}$. These depths are consisting with a melting source located just under the sub-lithosphere mantle. The same hypothesis has previously been proposed by Nono et al. (1994) for the Nganha volcano in the Adamawa plateau and the Upper Benue valley volcanism (Ngounouno et al. 2003) in the Cameroon Volcanic Line.

As previously suggested, trachyandesite and basanite lavas do not belong to the same lava series. The pretrogenesis of trachyandesite lava is discussed in term of fractional crystallization process. The mineral phases involved in this process are apatite, alkali feldspar and Fe-Ti oxides. This hypothesis is substantiated by the $\mathrm{P}, \mathrm{Sr}$ and Ti negative anomalies in the spider diagram (Fig. 4) while the positive anomalies in $\mathrm{Nb}$ and Ta exclude any interaction between trachyandesite lava and the continental crust materials.

\section{Conclusions}

Tchabal Mbabo volcano in the Adamawa plateau was built up during Eocene-Oligocene. Trachyandesites excepted, basalt and basanite lavas belong to the same magmatic series. Basanite lavas are the result of low partial melting of about $2 \%$ rate of the sublithospheric mantle source, containing residual garnet and phlogopite phases. The formation of the Cameroon Line is difficult to council with any space-time relationships, especially the hot-spot model suggested by the previous works.

\section{Acknowledgments}

The authors warmly thank the "Agence Universitaire de la Francophonie (AUF)" for financial support of this study, from the field works to laboratory analyses. They also are grateful to the "Association des Universités Africaines (AUA)" for supplementary analyses and commodities.

\section{References}

[1] Aka FT, Nagao K, Kusakabe M, Sumino H, Tanyileke G, Bekoa A \& Hell J (2004) Symmetrical Helium isotope distribution on the Cameroon Volcanic Line, West Africa. Chemical Geology 203, 205-223.http://dx.doi.org/10.1016/j.chemgeo.2003.10.003

[2] Aka FT, Nagao K, Kusakabe M \&Nfomou N (2009).) Cosmogenic helium and neon in mantle xenoliths from the Cameroon Volcanic Line (West Africa): Preliminary observations. Journal of African Earth Sciences 55, 175184.http://dx.doi.org/10.1016/j.jafrearsci.2009.04.002.

[3] Bellon H \& Rangin C (1991) Geochemistry and isotopic dating of Cenozoic volcanic arc sequences around the Celebes and Sulu Seas. In Proceedings of the Ocean Drilling Program (Silver EA, Rangin C, Breymann MT ed.), Scientific Results 124, pp 321338.http://dx.doi.org/10.2973/odp.proc.sr.124.163.1991.

[4] Carignan J, Hild P, Mévelle G, Morel J \&Yeghicheyan D (2001) Routine analyses of trace elements in geological samples using flow injection and low pressure on-line liquid chromatography coupled to ICP-MS: a study of geochemical reference materials BR, 
DR-N, UB-N, AN-G and GH. Geostandards Newslett 25, 187 198.http://dx.doi.org/10.1111/j.1751-908X.2001.tb00595.x

[5] Charbit S, Guillou H \& Turpin L (1998) Cross calibration of K-Ar standard minerals using an unspikedAr measurement technique. Chemical Geology 150, 147-159.http://dx.doi.org/10.1016/S00092541(98)00049-7.

[6] Chauvel C, Hofmann AW \& Vidal P (1992) HIMU-EM: The French Polynesian connection. Earth Planet Science Letters 110 99-119.http://dx.doi.org/10.1016/0012-821X(92)90042-T.

[7] Déruelle B, Moreau C, Nkoumbou C, Kambou R, Lissom J, Njonfang E, Ghogomu RT \&Nono A (1991) The Cameroon Line: a review. In Magmatism in Extensional Structural Settings (Kampunzu AB \&Lubala $\mathrm{R}$ eds.), Springer-Verlag, Berlin, 274327.http://dx.doi.org/10.1007/978-3-642-73966-8_12.

[8] Déruelle B, Ngounouno I \&Demaiffe D (2007) The 'Cameroon Hot Line' (CHL): a unique example of active alkaline intraplate structure in both oceanic and continental lithospheres. ComptesRendus Geosciences 339 , 600.http://dx.doi.org/10.1016/j.crte.2007.07.007.

[9] Déruelle B (1994) Le magmatisme de la "Ligne du Cameroun': le bilanpositif des deuxdernièresdécennies de coopération FrancoCamerounaise. Pangea, 30-36.

[10] Dorbath C, Dorbath L, Fairhead JD \& Stuart GW (1986) ateleseismic delay time study across the Central African Shear Zone in the Adamawa region of Cameroon, West Africa. Geophys. J. R. Astr. Soc. $\quad 86, \quad 751-766$. http://dx.doi.org/10.1111/j.1365246X.1986.tb00658.x.

[11] Dorbath L, Dorbath C, Stuart GW \&Fairhead JD (1984) Structure de la croûte sous le plateau de l'Adamaoua (Cameroun). C. R. Acad Sci. Paris 298, 539-542.

[12] Dunlop HM (1983) Strontium isotope geochemistry and potassiumargon study on volcanic rocks from the Cameroon Line,West Africa. PhD Thesis, Univ. Edinburgh, UK.

[13] Fagny AM, Nkouandou OF, Déruelle B \& NGOUNOUNO I (2012) revised petrology and new chronological data on the peralkaline felsic lavas of Ngaoundéré volcanism (Adamawa Plateau, Cameroon, Central Africa): evidence of open-system magmatic processes. AnaleleStiintifice ale Universitatii "Al. I. Cuza" din Iasi SeriaGeologie 58, 5-22.

[14] Fitton JG \& Dunlop HM (1985) The Cameroon Line, West Africa and its bearing on the origin of oceanic and continental alkali basalt. Earth. Planet. Sci. Lett. 72, 23-38.http://dx.doi.org/10.1016/0012821X(85)90114-1.

[15] Fitton JG (1980) The Benue trough and Cameroon line-a migrating rift system in West Africa. Earth and Planetary Science Letters 51 132-138

[16] Fitton JG (1987) The Cameroon line, West Africa: a comparison between oceanic and continental alkaline volcanism. In Alkaline Igneous Rocks (Fitton JG \& Upton BCG eds). Geol. Soc., London, 273-291. http://dx.doi.org/10.1144/gsl.sp.1987.030.01.13.

[17] Fitton JG (1983) Active versus passive continental rifting: evidence from the West African rift system. Tectonophysics 94, 473-481. http://dx.doi.org/10.1016/0040-1951(83)90030-6.

[18] Fuhrmann U, Lippolt H \& Hess JC (1987) HD-B1 Biotite reference material for K-Ar chronometry. Chemical Geology 66, 41-51.

[19] Ganwa AA, Frisch W, Siebel W, Ekodeck GE, Cosmas SK \&Ngako V (2008) Archean inheritances in the pyroxene-amphibole bearing gneiss of the Méiganga area (Central North Cameroon) Geochemical and $207 \mathrm{~Pb} / 206 \mathrm{~Pb}$ age imprints. C. R. Géosciences 340, 211-222.http://dx.doi.org/10.1016/j.crte.2007.12.009.

[20] Gouhier J, Nougier J \&Nougier D (1974) Contribution à l'étudevolcanologique du Cameroun: Ligne du CamerounAdamaoua. Annales Fac. Sci., Cameroun 17, 3-49.

[21] Hautmann S \&Lippolt HJ (2000) Ar-40/Ar-39 dating of central European K-Mn oxides - a chronological framework of supergene alteration processes during the Neogene. Chemical Geology 170, 1-4, 37-80.http://dx.doi.org/10.1016/S0009-2541(99)00241-7.

[22] Hess JC \&Lippolt HJ (1994) Compilation of K-Ar measurements on HD-B1 standard biotite. Odin, G.S. (Ed.), Phanerozoic Time scale. Bulletin Liaison Informations, I.U.G.S. Subcommission on Geochronology 12, 19-23.

[23] Hofmann AW (1988) Chemical differentiation of the Earth: the relationship between mantle, continental crust, and oceanic crust Earth and Planetary Science Letters 90, 297 314.http://dx.doi.org/10.1016/0012-821X(88)90132-X.

[24] Kamdem JB, Kraml M, Keller J, Henjes-Kunst F (2002) Cameroon Line magmatism: conventional $\mathrm{K} / \mathrm{Ar}$ and single-crystal laser 40Ar/39Ar ages of rocks and minerals from the HossereNigoanorogenic complex, Cameroon. Journal of African Earth Sciences 35, 1, 99-105.http://dx.doi.org/10.1016/S0899-5362(02)00002-7.
[25] Kamgang P, Njonfang E, Nono A, Dedzo MG \&Tchoua FM (2010) Petrogenesis of a silicic magma system: Geochemical evidence from Bamenda Mountains, NW Cameroon, Cameroon Volcanic Line. Journal of African Earth Sciences 58, 285304.http://dx.doi.org/10.1016/j.jafrearsci.2010.03.008

[26] Kampunzu AB \&Popoff M (1991) Distribution of the main Phanerozoic African rifts and associated magmatism: introductory notes. In Magmatism in Extensional Structural Settings, the Phanerozoic African Plate (Kampunzu AB \&Lubala RT eds.), Springer-Verlag, Berlin, 2-10.http://dx.doi.org/10.1007/978-3-642-73966-8_1.

[27] Le Maitre RW (2002) Igneous Rocks - A Classification and Glossary of Terms. Recommendations of the IUGS Sub-Commission on the Systematics of Igneous Rocks. 2nd edn, Cambridge University Press, Cambridge 236.http://dx.doi.org/10.1017/CBO9780511535581.

[28] Leake BE, Woolley AR, Arps CES, Birch WD, Gilbert MC, Grice JD, Hawthorne FC, Kato A, Kisch HJ, Krivovichev VG, Linthout K Laird J, Mandarino JA, Maresch WV, Nickel EH, Rock NMS, Schumacher JC, Smith DC, Stephenson NCN, Ungaretti L, Whittaker EJW \&Youzhi G (1997) Nomenclature of amphiboles: report of the subcommittee on amphiboles of the international mineralogical association, commission on new minerals and mineral names. The Canadian Mineralogist 35, 219. 246.http://dx.doi.org/10.1180/minmag.1997.061.405.13.

[29] Lee DC, Halliday AN, Fitton JG \&Poli G (1994a). Isotopic variations with distance and time in the volcanic islands of the Cameroon line: evidence for a mantle plume origin. Earth lume origin. Earth Planet. Sci. Lett. 123, 119-138.

[30] Lee DC, Halliday AN, Hall CM \&Fitton JG (1994b) Similarities and differences between continental and oceanic basalts in the Cameroon Line (abstract). Eighth International Conference on Geochronology, Cosmochronology and Isotope Geology, Berkeley, pp 188.

[31] Marzoli A, Renne PR, Piccirillo EM, Castorina F, Bellieni G, Melfi AJ, Nyobe JB \&N'ni J (1999) silicic magmas from the continental Cameroon Volcanic Line (Oku, Bambouto and Ngaoundere):40Ar39Ar dates, petrology, Sr-Nd-O isotopes and their petrogenetic significance. Contrib. Mineral. Petrol. 135, 133150.http://dx.doi.org/10.1007/s004100050502.

[32] Mbowou GIB, Lagmet C, Nomade S, Ngounouno I, Déruelle B \&Ohnenstetter D (2012) Petrology of the Late Cretaceous peralkaline rhyolites (pantellerite and comendite) from Lake Chad, Central Africa. Journal of Geosciences 57, 127 141.http://dx.doi.org/10.3190/jgeosci.118.

[33] Moreau C, Regnoult JM, Déruelle B \&Robineau B (1987) A new tectonic model for the cameroun line, central Africa. Tectonophysics 139, 317-334. http://dx.doi.org/10.1016/0040-1951(87)90206-X

[34] Morgan WJ (1971) Convective plumes in the lower mantle. Nature 230, 42-43. http://dx.doi.org/10.1038/230042a0.

[35] Morgan WJ (1972a).) Deep mantle convection plumes and plate motions. Bull. Am. Assoc. Pet. Geol. 56, 203-213.

[36] Morgan WJ (1972b) Plate motions and deep mantle convection. Geol. Soc. Am 132 22.http://dx.doi.org/10.1130/MEM132-p7.

[37] Morimoto N, Fabriès J, Ferguson AK, Ginzburg IV, Ross M, Seifert FA, Zussman J, Aoki K \&Gottardi G (1988) Nomenclature of pyroxenes. Mineral. $\quad$ Mag. 52, 550.http://dx.doi.org/10.1180/minmag.1988.052.367.15

[38] Ngounouno I, Déruelle B, Demaiffe D \&Montigny R (2003) Petrology of the Cenozoic volcanism in the Upper Benue valley, northern Cameroon (Central Africa). Contrib. Mineral. Petrol. 145 87-106.http://dx.doi.org/10.1007/s00410-002-0438-6.

[39] Nkouandou OF, Ngounouno I \&Deruelle B (2010) Géochimie des laves basaltiquesrécentes des zones Nord etEst de Ngaoundéré (Cameroun, Plateau de l'Adamaoua, Afriquecentrale): pétrogenèse et nature de la source. International Journal of Biological and Chemical Sciences 4, 984-1003.

[40] Nkouandou OF, Ngounouno I, Déruelle B, Onhenstetter D, Montigny R \&Demaiffe D (2008) Petrology of the Mio-Pliocene Volcanism to the North and East of Ngaoundéré (Adamawa-Cameroon). ComptesRendus Geoscience $\quad 340, \quad 28$ 37.http://dx.doi.org/10.1016/j.crte.2007.10.012.

[41] Nono A, Déruelle B, Demaiffe D \&Kambou R (1994) Tchabal Nganha volcano in Adamawa (Cameroon): petrology of a continental alkaline lava series. J. Volcanol. Geotherm. Res. 60, 147178.http://dx.doi.org/10.1016/0377-0273(94)90066-3.

[42] Pouchou JL \&Pichoir F (1991) Quantitative analysis of homogeneous or stratified microvolumes applying the model "PAP". In Electron Probe Quantification (Heinriche DE ed.). Plenum Press, New York, 31-75. http://dx.doi.org/10.1007/978-1-4899-2617-3 4 
[43] Scarrow JH \& Cox KG (1995) Basalts generated by decompressive adiabatic melting of a mantle plume: a case study from the Isle of Skye, NW Scotland. Journal of Petrology 36, 322.http://dx.doi.org/10.1093/petrology/36.1.3.

[44] Tchameni R, Pouclet A, Penaye J, Ganwa AA \&Toteu SF (2006) Petrography and geochemistry of the Ngaoundéré Pan-African granitoids in central North Cameroon: implications for their sources and geological setting. J. Afr. Earth Sci. 44, 511529.http://dx.doi.org/10.1016/j.jafrearsci.2005.11.017.

[45] Temdjim R, Njilah IK, Kamgang P, Nkoumbou C (2004) Donnéesnouvellessur les laves felsiques de Ngaoundéré (Adamaoua, ligne du Cameroun): chronologie K-Ar et pétrologie. African Journal of Science and Technology Science and Engineering 5, 2, 113-123.

[46] Wandji P, Tsafack JPF, Bardintzeff JM, Nkouathio DG, Kagou DA, Bellon H \&Guillou H (2009) Xenoliths of dunites, wehrlites and clinopyroxenite in the basanites from Batoke volcanic cone (Mount Cameroon, Central Africa): petrogenetic implications. Mineralogy and Petrology 96, 81-98.http://dx.doi.org/10.1007/s00710-0080040-3.

[47] Wilson JT (1973) Mantle plumes and plate motions. Tectonophysics 19, 149-164.http://dx.doi.org/10.1016/0040-1951(73)90037-1.

[48] Wilson WJ 1965. Evidence from ocean islands suggesting movement in the earth, Philos. Trans. R. Soc. London 258, 145167.http://dx.doi.org/10.1098/rsta.1965.0029. 